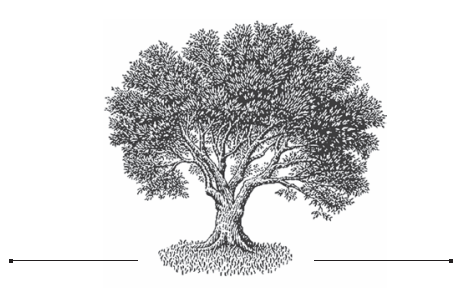

Потерянный рай протопопа Аввакума:

сочинение

«Снискание и

собрание о Божестве

и о твари»

как интерпретация

библейской истории*

Archpriest Avvakum's Paradise Lost: The Treatise Sniskanie i Sobranie o Bozhestve i o Tvari as Interpretation of Biblical History

\title{
Ольга Чадаева
}

\section{Olga Chadaeva}

Университет им. Палацкого в Оломоуце, Чехия

Palacký University Olomouc,

Czech Republic

\section{Резюме}

Статья посвящена интерпретации библейской истории в редко изучаемом сочинении протопопа Аввакума «Снискание и собрание о Божестве и о твари». Рассматриваются такие вопросы, как источники и цели этого произведения, виды и функции цитирования, структурная организация текста и его стиль, восприятие Бога, образ мира и рая, представление о человеке и

* Работа была выполнена при поддержке гранта Министерства образования, молодежи и спорта Чешской Республики IGA_FF_2017_026 Text a intertextualita ve slovanských literaturách a kultuře 1 .

\footnotetext{
Цит и ров ан ие: Чадаева О. Потерянный рай протопопа Аввакума: сочинение «Снискание и собрание о Божестве и о твари» как интерпретация библейской истории // Slověne. 2019. Vol. 8, № 1. C. 188-222. Citation: Chadaeva O. (2019) Archpriest Avvakum's Paradise Lost: The Treatise Sniskanie i Sobranie o Bozhestve i o Tvari as Interpretation of Biblical History. Slověne, Vol. 8, № 1, p. 188-222.

DOI: $10.31168 / 2305-6754.2019 .8 .1 .7$
} 
грехопадении, ходе и смысле истории, течении времени, родь автора и читателя в сочинении. Центральное место в этом полемическом произведении занимает тезис о необъятности Божества, проявляющейся как в пространственном, так и во временном отношении. Упрощенность представлений Аввакума о структуре физического мира рассматривается в контексте целостного мировосприятия автора. Акцентируется понимание Аввакумом сотворения Адама как узлового момента, предопределившего эсхатологический план истории. Исследуются пространственные и темпорадыные представления Аввакума и их проявление в тексте произведения, в особенности на уровне чередования прошлого, настоящего, будущего и вневременного планов, раскрывающие отношение автора к ходу и смыслу истории. «Снискание и собрание» представляет собой текст со структурой, зеркально противопоиожной «Житию протопопа Аввакума, им самим написанному», где конкретные события настоящего соотносятся со священной историей, тогда как в «Снискании» библейские события соотносятся с современностью. Продемонстрирована многоплановость текста Аввакума, выстроенного одновременно как полемическое сочинение, рассказ и диалог с читателем. В заключении сопоставлены интерпретации событий Книги Бытие у Дж. Мильтона в поэме «Потерянный рай» и в «Снискании и собрании» протопопа Аввакума. Сочинения отразили как сходные, так и совершенно раздичные проблемы в связи с грехопадением и изгнанием человека из рая.

\section{Ключевые слова}

Аввакум, «Снискание и собрание о Божестве и о твари», дитература XVII в., рай, Адам, грехопадение, ход истории, библейская история, модель мира, Джон Мильтон, «Потерянный рай»

\section{Abstract}

The paper focuses on interpretation of Biblical history in a lesser-known treatise written by Archpriest Avvakum entitled Sniskanie i sobranie o Bozhestve i o tvari. The main issues addressed in the paper are the sources and aims of the treatise, methods and functions of citing, structure and style of the text, the perception of God, the imagery of the world and paradise, the notion of mankind and fall of man, the progress and sense of history, the flow of time, the role of the author and the reader in the text. Central to this polemical treatise is the thesis of the immensity of God, which manifests itself both in spatial and in temporal aspects. The simplicity of Avvakum's notion of the physical world is considered in the context of the author's holistic worldview. An emphasis is put on the perception of the creation of Adam as a key moment that predetermined the eschatological plan of history. The paper traces the spatial and temporal imagery of Avvakum and its manifestation inside the text, specifically in the alteration of the past, present, future and infinite planes of reality, which reveals Avvakum's attitude to the process and meaning of history. Sniskanie i sobranie is a text whose structure is a reverse reflection of the major work of Avvakum, i.e. his Life, where the events of the present are referred to the the sacred history, while in Sniskanie Biblical events are compared to the present. The versatility of Sniskanie $i$ sobranie is demonstrated through its multiple functions, since the text is built as a polemical treatise, 
narrative and a dialogue. In conclusion, the interpretation of the events of the Book of Genesis by Avvakum is compared to John Milton's poem Paradise Lost. The works reflected both similar and entirely different problems in connection with the fall of man and the loss of paradise.

\section{Keywords}

Archpriest Avvakum, Sniskanie i sobranie o Bozhestve i o tvari, Russian 17th century literature, paradise, Adam, fall of man, historical process, biblical history, model of the world, John Milton, Paradise Lost

\section{Введение}

Общий кризис XVII в. во всей Европе в его политических, экономических, демографических, гносеологических или общекультурных аспектах стал предметом изучения не одного поколения историков и литературоведов [Burke 2009: 239]. Ощущение потери, поиск новой точки отсчета и пересмотр понимания места человека в мире, попытка установить новые связи человека с Богом - вот те темы, которые волнуют авторов начала Нового времени. И если достаточное внимание исследователей уделялось творчеству западноевропейских писателей и поэтов, отразившему кризисный характер эпохи, который в том числе проявился в переосмыслении библейской истории, в первую очередь, в поэме «Потерянный рай» Дж. Мильтона, то тематика «потерянного рая» в произведениях русских авторов остается пока изученной недостаточно. При этом в России во второй половине XVII в. появляется оригинальный текст, посвященный представлению о потерянном рае и интерпретации начальных глав Книги Бытие - сочинение «Снискание и собрание о Божестве и о твари» протопопа Аввакума.

Протопоп Аввакум играл выдающуюся роль в культуре переходного периода. Он выступал сразу в нескольких ролях: защитника традиционных ценностей, литературного новатора, полемиста (причем полемика велась сразу по двум направлениям - как против никониан, так и против идеологических противников внутри старообрядческого движения) [Панченко 1980: 391-396]. Хотя в значительной мере внимание исследователей было сосредоточено на полемике Аввакума против сторонников церковной реформы, его участие во внутренних идеологических спорах среди раскольников представляет не меньший интерес при изучении его полемической деятельности. Наибольшее же внимание и теперь привлекает агиографическо-автобиографическая деятельность протопопа Аввакума [Лавров 2018: 11-12]. Произведения Аввакума 
традиционно изучались с точки зрения стилистики, трансформации агиографического жанра, народного влияния на литературу переломного периода, демократизации русской литературы, а также богословских, философских и антропологических аспектов, причем последним уделено несколько меньше внимания [Лыткин, Осипова 2015: 77-84].

Сочинение «Снискание и собрание», находясь в тени «Жития протопопа Аввакума, им самим написанного», получило незаслуженно мало внимания специалистов, на что еще в 1975 г. указывали издатели так называемого Пустозерского сборника - автографа (автографов) сочинений Аввакума и Епифания [Аввакум 1975: 179], и с тех пор ситуация принципиально не менялась. Это не значит, что сочинение вообще не учитывалось исследователями творчества Аввакума - упоминания о нем мы найдем в том числе в работах П. Хант [Hunt 1975-76: 159-163; Хант 1977: 73-74], М. Б. Плюхановой [Плюханова 1996: 414], Д. С. Менделеевой [Менделеева 2005: 196-199] и других исследователей, однако самостоятельных работ по «Снисканию и собранию» нет.

Задача настоящей работы состоит в том, чтобы рассмотреть интерпретацию в этом сочинении первых событий Книги Бытие, авторское видение мироздания, отношение к Богу и процессу творения, образ первого человека, представления о рае и восприятие его потери, понимание хода и смысла истории, а также коммуникативные стратегии при выстраивании текста. В заключительной части статьи видение библейской истории у Аввакума сопоставляется с ключевым для европейской культуры текстом - вышеупомянутым «Потерянным раем» Джона Мильтона.

\section{1. Создание, структура, источники, особенности «Снискания и собрания»}

Текст «Снискания и собрания» дошел до нас в составе Пустозерского сборника. Он проливает свет на глубинные онтологические представления, бытовашие в среде раскольников XVII в. Сочинение было написано в 1672 г., когда Аввакум провел уже пять лет в Пустозерске [Аввакум 1975: 185]. Лишенный возможности активно принимать участие в событиях религиозной жизни, Аввакум, как и другие пустозерские сидельцы, посвятил себя единственной возможной форме деятельности - влиянию на души и умы современников и сподвижников своими сочинениями, в чем вскоре занял ведущую позицию [Герасимова 2012: 253].

Рассматриваемый текст также известен под следующими названиями: «Собрание о сотворении мира и человека», «Списание и собрание о Божестве и о твари» и проч. Именно слово «снискание» отражает суть текста наиболее полно: это искание, поиски, исследования, следствие 
трудов, стараний, усердий, но также и сочинение [CPЯ XI-XVII 2000: 261-262]; т. е. вся информация, предоставляемая в тексте, - плод длительных исканий, и, сведенная воедино, она становится своего рода компендиумом, за которым стоит долгая история сбора и осмысления сведений. Внешним импульсом для создания сочинения послужили еретические, по мнению Аввакума, представления, распространившиеся в раскольничьей среде из-за возросшей популярности апокрифического сочинения «Беседа трех святителей». Этот апокрифический памятник построен в форме вопросов и ответов, изложенных от имени Василия Великого, Иоанна Златоуста и Григория Богослова. Сам по себе текст известен в Древней Руси по меньшей мере начиная с XIV в. (так как включается в списки отреченных книг), древнейший сохранившийся древнерусский список относится к XV в. [Лурье 1988]. В тексте апокрифа, где весьма сильно прослеживаются фольклорные влияния, рассматриваются разнообразные темы: первое существо на Земле (Сатанаил), символическая трактовка высоты, широты и глубины как трех лиц Троицы, местопребывание Бога до момента творения, создание ангелов из света и огня, создание небесных светил и природных явлений, образы евангелистов как четырех частей света, сотворение Адама из восьми частей, количество морей, высоких гор, рек, островов, количество костей и суставов у человека и др. [Беседа трех святителей 1862: 169-178] $]^{1}$. Новейшие исследования памятника показывают, что существовало по меньшей мере десять русских редакций текста «Беседы» [Бабалык 2011: 108-109]. Сам по себе факт распространения этого текста в раскольничьей среде заслуживает, вне всякого сомнения, отдельного внимания, однако для нас оно важно как внешний импульс, послуживший поводом для написания сочинения Аввакума. Утверждения, против которых выступает Аввакум, а именно локализация Бога до сотворения мира в трех «камарах» (сводах, покоях, см.: [CPЯ XI-XVII 1980: 260]), сотворение ангелов из Святого Духа, происхождение солнца от ризы господней, а месяца - от духа и престола, сотворение земли из пены и ее расположение на китах [Аввакум 1975: 92, 97-99], дают основание предположить, что основой для полемики послужила так называемая Троицкая редакция «Беседы», где рассматриваются все вышеперечисленные вопросы [Бабалык 2011: 65-66, 237-238], тогда как в других, более поздних редакциях данные вопросы либо встречаются в разных комбинациях, либо отсутствуют.

Интересен для размышления вопрос о том, какие причины побудили Аввакума, полемизировавшего с апокрифом, написать свой

1 В данной работе ссылки приводятся на это издание, так как в нем отражены те вопросы и ответы, с которыми полемизирует Аввакум. 
собственный текст, интерпретирующий события первых дней творения, а не кратко осудить распространение апокрифических представлений и сослаться на какой-либо авторитетный текст, напр. на «Шестоднев» Иоанна экзарха Болгарского, подробно освещающий заявленную тему и ставший для Аввакума важным источником [Сарафанова-Демкова 1963]. Один из возможных ответов - включение текста в сборник наравне с автобиографическим «Житием». Будучи созданным уже после «Жития», «Снискание и собрание» дает дополнительный контекст для интерпретации мировоззрения Аввакума. Если «Житие» разворачивает перед читателем картину биографии автора на фоне глобального контекста истории, то «Снискание и собрание» можно рассматривать как комментарий, пояснение не к конкретной биографии, а к истории как таковой, включающей сотворение человека, грехопадение, вочеловечение Христа и в перспективе - Второе пришествие [Hunt 1975-76: 159-163]. В этом смысле «Снискание и собрание» становится как бы оборотной стороной «Жития», где жизнь автора соотносится с библейской историей [Герасимова 2012: 244]. «Снискание и собрание» же соотносит события библейской истории с современностью, причем не с жизнью конкретной личности, а с обществом в целом.

По своей структуре «Снискание и собрание», хотя и написанное как гомогенный текст, делится на следующие тематические разделы.

1. Вводная «обличительная» часть, открывающаяся цитатой из Евангелия [Ин 8:42-44], где Аввакум обозначает главный тезис, о котором ведется полемика - местопребывание Бога до момента сотворения мира (согласно «Беседе трех святителей» - некие три «камары»).

2. Развитие полемики - аргументы в пользу невместимости и безграничности Бога, подтверждаемые примерами из Ветхого Завета и Откровения (наиболее развернутые цитаты).

3. Следующий «ложный» тезис - происхождение ангелов от Святого Духа и его опровержение с аргументами в пользу «приведения от небытия в бытие».

4. Тезис «Беседы трех святителей» о происхождении солнца от ризы господней, месяца от престола господнего, земли от пены морской и утверждении земли на трех больших китах. Опровержение тезиса и описание мира согласно представлениям автора, отталкивающееся от Книги Бытие и космологической компиляции в составе «Хронографа».

5. Рассказ о сотворении человека и его грехопадении.

6. Рассказ о жизни Адама и его потомков после грехопадения.

7. Рассказ о потопе и его последствиях.

8. Обличение «волхвов и звездочетцев», пытающихся выяснить будущее, рассказ о Невроде (Нимроде) и вавилонском столпотворении. 
9. Краткий пересказ последующих событий Пятикнижия, после чего следует заключение, в котором идет речь о вочеловечении Иисуса Христа.

Таким образом, в тексте, начатом полемикой с апокрифическим сочинением, описываются события первых дней творения и коротко освещаются события библейской истории вплоть до рождения Иисуса Христа. Также в тексте затрагиваются гносеологические вопросы, что сближает его по структуре с «Палеей Толковой», точно так же отталкивающейся в своей первоначальной редакции от полемической интенции (антииудейских обличительных толкований) и далее представляющей мир и историю в их эсхатологической перспективе [Мильков 2009b: 159]. Но основа этого текста не абсолютна, поскольку Аввакум постоянно ведет диалог с читателем, а ветхозаветные события соотносит с современностью.

Ветхозаветное основание текста представляет собой лишь первый уровень: помимо цитат из Священного Писания, причем не только из Книги Бытие, но и других разделов Ветхого и Нового Завета, текст пестрит прямыми ссылками на множество других источников, среди которых мы найдем в первую очередь «Гранограф», т. е. «Хронограф» (упоминается шесть раз), гимнографические тексты (четыре упоминания), Иоанна Златоуста (три упоминания), Символ веры, сочинения Дионисия Ареопагита, Василия Великого, Иоанна Дамаскина, Патрикия Прусского, Филона, «Палею» (по одному упоминанию). Эти сочинения, упомянутые прямо, следует рассматривать отдельно, поскольку они авторитетны как для Аввакума, так и для его читателей. Частое повторение «Гранографа» наводит на мысль о том, что для Аввакума, живущего в эпоху динамических перемен и активно принимающего в этих переменах участие, было важным искать точку стабильности в истории, в первой очереди в истории священной, вневременной. Эта тенденция, выделенная С. Матхаузеровой [1976: 125] на основании лингвистического анализа глагольных времен в текстах Аввакума, прослеживается в настойчивой отсылке к хронографии. Характер ссылок на «Хронограф» говорит о том, что может иметься в виду не только текст космогонической компиляции, вошедший в «Русский хронограф» 1512 г. и практически в неизменном виде включавшийся в тексты последующих редакций [Буланин 2016: 122-123], но и в том числе обширная компиляция, посвященная творению и космоустроению и предваряющая текст 2-го разряда редакции «Хронографа» 1620 г. [Попов 1869: 154-155]².

\footnotetext{
В статье приводятся ссылки на работы А. Н. Попова, а не на более актуальные работы О. В. Творогова и Е. Г. Водолазкина, так как именно А. Н. Попов подробно рассматривал включенную во вторую разновидность последней
} 
В основу этого компилятивного сочинения, озаглавленного «О сотворении седми день и всего мира», легли такие тексты, как «Маргарит» Иоанна Златоуста, «Шестоднев» ${ }^{3}$, Житие св. Андрея Юродивого Царьградского», «Прение Панагиота с Азимитом», «Луцидариус» и «Книга Eноха» [Ibid.], сочинения Максима Грека [Беляев 1913: 4], а также, как показывают новейшие (к сожалению, пока единичные) исследования этого текста, космологическая компиляция «Слово о Святой Троице» [Савельева 2007: 571-572].

Исследователи выделяют в творчестве Аввакума целый ряд функций цитат, среди которых в «Житии» доминируют этикетная, коммуникативная, морально-дидактическая и полемическая, но также выявляются догматическая, экзегетическая функции и функция моделирования текста по образцу сакрального [Герасимова 2012: 235]. Поскольку текст «Снискания и собрания» резко отличается от «Жития» по изначальной интенции, цитаты здесь более развернуты и выполняют иные цели. В первой части, посвященной вопросу невместимости и необъятности Бога, Аввакум ссылается в первую очередь на Священное Писание [Аввакум 1975: 92-96], и здесь догматическая и экзегетическая функции доминируют, перекрываясь с полемической и морально-дидактической, однако дальше чередуются отсылки и к другим источникам. Упоминая наряду с Книгой Бытие прочие авторитетные тексты, в том числе «Гранограф», «Слово Патрикия Прусского» и «Маргарит», Аввакум снова возвращается к библейскому тексту: «Паки на первое возвратимся, отнележе изыдохом» [Аввакум 1975: 101]. Это возвращение («Паки Бытия», «Еще побъсъдуем о вышереченной Бытии») становится в тексте структурообразующим и используется в том числе для введения новой темы, завершая авторские размышления и отступления.

Сквозь призму «Снискания и собрания» можно взглянуть на значительную часть круга чтения Аввакума. Связь с некоторыми святоотеческими текстами можно проследить косвенно, на основании отсылок в других его сочинениях - в первую очередь речь идет о «Шестодневе» Иоанна экзарха Болгарского [Сарафанова-Демкова 1963]. Еще более интересными, но не цитируемыми прямо источниками пред-

большой редакции текста «Хронографа» космологическую компиляцию, тогда как работа по современному изучению проблемы только предстоит [Буланин 2016: 123].

3 А. Н. Попов относит заимствования к «Шестодневу» Василия Великого, однако вопрос применительно к тексту компиляции нуждается в дополнительном изучении, так как, возможно, речь идет о «Шестодневе» Иоанна экзарха Болгарского, содержащего обширные заимствования из сочинения Василия Великого. Полный же текст «Шестоднева» Василия Великого до 1656 г., когда вышло его издание, был известен лишь ограниченному кругу читателей [Мильков 2008а: 39]. 
ставлений, тем и мотивов в тексте можно считать апокрифические тексты [Сарафанова 1962: 329-340]. В тексте отмечено влияние таких апокрифов, как «О небеси», целый комплекс апокрифов о создании Адама и Евы и о грехопадении, апокрифы о Енохе (возможно, почерпнутые именно из космологической компиляции, предваряющей вторую разновидность «Хронографа» редакции 1620 г.), «Слово Мефодия Патарского» [Аввакум 1975: 243-248].

Аввакум чередует и методы заимствования: некоторые тексты попадают в произведение целиком и без изменений (в первую очередь это касается цитат из Священного Писания), другие же являются объектом свободной интерпретации, что усиливает стилистическую неоднородность сочинения, которая свойственна творчеству Аввакума [Виноградов 1980: 13-15]. От книжного стиля, использованного в цитировании, Аввакум переходит к разговорному: часто употребляет императив, фразеологизмы, инвективы. Тон самого автора динамично меняется: мы можем наблюдать возмущенного полемиста, убежденного рассказчика, язвительного комментатора. Текст распадается на два уровня: повествование о Боге, сотворении мира, первом человеке и его падении, истории до рождения Христа и диалог Аввакума с читателем, актуальным «слышателем», заблудшим учеником. Таким образом, этот текст, как и «Житие», отмечен стилистической и структурной двуплановостью, психологическим параллелизмом [Виноградов 1980: 9; Робинсон 1967: 362]. Однако картина повествования в «Снискании и собрании» по сравнению с «Житием» перевернута, так как если в «Житии» Аввакум соотносит свою жизнь с событиями священной истории, то в «Снискании», наоборот, библейские события соотносятся с современностью.

\section{2. Бог и Творец}

Весь текст «Снискания и собрания» отталкивается от идеи необъятности Бога, это тезис, который выводится в качестве обоснования самого написания текста, ведущего полемику с представлением о «камарах», или покоях, в которых находились божественные ипостаси до сотворения мира. Для Аввакума Божество «неприступно [...] и непостижно, и непостоянен б(о)гъ во едином мъсте» [Аввакум 1975: 93].

Всесущий Бог является человеку «по схождению» - это эпизоды из Быт 18:1-10, Ид 33:23, Ис 6:1-3, Ис 7:14. Кроме схождения, есть еще явление Бога на престоле - это ключевые эпизоды из Иез 1:26 (Меркаба), Дн 7:9 («Ветхий днями»), Откр 1:10-19, Откр 4:1-11 [Аввакум 1975: 93-96]. Различия в локализации Бога («камара» и «престол») могут интерпретироваться как противоположность субъектно-объектных 
отношений: если Бог, заключенный в некоем месте, становится объектом, помещенным в данный локус, то Бог, водружающий сам себя на престол, играет роль субъекта, и его явление становится актом воли, реализацией интенции, никак не ограниченной какими-либо пространственными рамками. Престолы Бога в понимании Аввакума «живые», т. е. принадлежат ноуменальной сфере и лишены инструментального значения ${ }^{4}$.

Необъятность и невместимость Бога определяется формулой: «Свђт б(о)гъ, но и не свђтъ, паче бо свђта; животъ б(о)гъ, но и не живот, паче бо живота» [Аввакум 1975: 97] ${ }^{5}$. В этом апофатическом определении Аввакум указывает на неограниченность Бога как в пространстве (свет), так и во времени (жизнь). Пространственно-временная проблематика в понимании Аввакума представляет единый комплекс:

Видищ(ь) ли, не сего видимаго свظта требуетъ б(о)гъ, иже нас ради сотворен, но той невещественный свђтъ прежде въкъ въчных. Много въковъ у вл(а)д(ы)ки было до сьго въка [...] Зри, отцы на первом соборђ рекоша: «Прежде многих векъ». От Адама г(лаго)лется един въкъ, а не многие [Аввакум 1975: 97].

Невозможность локализовать Бога в едином месте неразрывно связана с его бытием вне времени, и время, как его воспринимаем мы, - история человечества, «век Адама», - противопоставлено множественности «веков Бога». Последнее можно интерпретировать двояко: как допущение возможности существования иной темпоральности, предшествовавшей временной истории человечества и конкретного пространственно-временного континуума, возникшего в момент сотворения первого человека и неизбежно стремящегося ко Второму пришествию, так и в контексте парадигмы «прошлое - настоящее - будущее», касающейся исключительно тварного существования и физического мира. Бог при этом противопоставлен самому представлению о времени, существуя вне его, являясь его творцом, отправной и конечной точкой одновременно.

Вопрос о времени и предопределении с точки зрения Бога проявляется в коммуникативной ситуации, когда Бог решает создать человека и советуется с Сыном относительно своего плана, и именно в этот момент замыкается эсхатологический круг истории:

4 Здесь прослеживается связь с сочинением «О небесной иерархии» Псевдо-Ареопагита, где престолы, будто бы сделанные из дерева, названы «оскорбительными» для бесплотного мира [О небесной иерархии: 93, 230].

5 Ср. у Псевдо-Ареопагита: «Он больше всякой сущности и жизни, никакой свет [не может] начертать [Его]» [О небесной иерархии: 231]. 
И рече от(е)цъ с(ы)нови: «Сотворим ч(е)л(о)вька по образу нашему и по подобию». И отвњща другий: «Сотворим, отче, и преступит бо». И рече: «О единородный мой! О свђте мой, о с(ы)нъ и слове! О сияние славы моея! Аще промышляеши созданиемъ своим, подобает ти облещися в тлимаго ч(е)л(о) вька, подобает ти по земли ходити, ап(о)ст(о)лы восприяти, пострадати, воскреснути и вся совершити». И отвђща другий: «Буди, отче, воля твоя» [Аввакум 1975: 102].

Помимо отмеченных издателями текста внешних влияний на этот фрагмент «Слова о вочеловечении» Иоанна Златоуста, а также апокрифов «Сотворение Адама и Евы» и «Сказание об Адаме и Еве» [Аввакум 1975: 246], следует обратить внимание на отражение вопросов предопределения судьбы человечества и жертвы Христа. Примечателен тот факт, что у Аввакума весь эсхатологический план оформляется в тот момент, когда Бог сообщает Сыну решение о сотворении человека и последующем вочеловечении. Таким образом, акцент у Аввакума смещен в сторону роли именно человека. Его существованием не только определяется ход и конец истории, оно также играет решающую роль для действий одной из божественных ипостасей.

Неприступный и непостижимый Бог, в начале текста лишь являющийся человеку, по мере разворачивания библейских событий приобретает и человеческие черты. Впервые они проявляются в тот момент, когда Бог говорит с Сыном и позже творит человека «боголепными руками», тогда как все остальные акты творения являются вербальными. Тем не менее, по словам Аввакума, мы не можем понимать «руки» буквально: это метафорическое обозначение всех трех испостасей Троицы, участвовавших в творении, которое одновременно становится предопределением конца, завершения: «[Е]динъ сотворил, а другий и совершил повельниемъ отчимъ» [Аввакум 1975: 103].

В ходе нарратива и углубления Аввакума в интерпретацию истории постепенно сокращается и расстояние, отделяющее Бога от человека. Это проявляется как на повествовательном уровне, что обусловлено включением Бога в прямую коммуникацию с человеком после грехопадения (Быт 3:9-13; Быт 4:9-10; Быт 32:24-31), так и на стилистическом, когда Аввакум то обращается к Богу, используя разговорную формулу «Надежа-свет» [Аввакум 1975: 105], то, объясняя природу грома согласно библейской традиции как божественное волеизъявление (Пс 26:19), добавляет от себя: «Да вол(ь)но Х(рист)у: чем изволит, тьмъ и шумит» [Ibid.: 109]. Кроме того, ускоряется ход истории: рассказав о потопе и Ное, Нимроде и смешении языков, Аввакум уже не останавливается подробно на отдельных эпизодах, лишь перечисляя коротко библейские события и сокращенную родословную Христа. Моментом 
вочеловечения - максимальным приближением Бога - завершается все повествование: «Х(ристо)с смотрение свое совершилъ и нас ради вочеловьчился. Ему же слава со отцемъ и со с(вя)тым д(у)хом н(ы)нъ и пр(и)сно и во вЂки вЂкомъ. Аминь» [Ibid.: 112]. Таким образом, Бог в тексте совершает определенное движение: от явления на престоле к человеческой форме. Завершающая же текст традиционная формула «ныне и присно и во веки веком» возвращает читателя к вводной мысли автора - неограниченности Бога. Если в начале текста упор делался на пространственной неограниченности, то в конце это неограниченность темпоральная, подчеркнутая представлением о пространственной и временной ограниченности человеческой формы Христа.

\section{3. Мир}

Значительное внимание Аввакум уделяет сотворению мира и его устройству. Аввакум передает историю сотворения мира напрямую, ссылаясь лишь на авторитетные для него тексты. В понимании Аввакума видимый мир - продолжение, следствие и неделимая часть мира трансцендентного, что обусловлено всепроникающей сущностью Бога. Физический мир служит лишь дополнением к божественной вертикали-схождению и так же выстраивается по направлению сверху вниз от огненного неба к глубинам ада. Горизонталь же в этой системе представлена течением времени. Принципиально важным для Аввакума аспектом миропонимания становится понимание происхождения составляющих мироздания. В «Снискании и собрании» Аввакум противопоставляет вербальное творение («повелением») творению из первоэлементов, или, как представлено в апокрифической «Беседе трех святителей», божественных атрибутов - ризы Господней как первоэлемента для солнца, Духа Святого - для месяца, пены морской - для земли [Беседа трех святителей 1862: 169]. Аввакуму подобные спекуляции кажутся возмутительными, как и представление, что земля покоится на «тре $x$ бол(ь)ших кита $x$ да на тритцети малы $x$ », а море «на столбахъ утверженно», так как Господь повелел земле «на воде лежа $m($ ь), а не на кита $x$ ». Упоминается и утверждение земли «ни на чем» со ссылкой на Иоанна Дамаскина [Аввакум 1975: 98-99]. Вербальная природа творения активно постулируется Аввакумом: «А сотворил его б(о)гъ словом своим от несущества, сирђчь от небытия в бытие приведе. Слово б(о) жие живо и дьйственно» [Аввакум 1975: 98].

Несмотря на то что Божество всеобъятно и пронизывает собой мироздание, ноуменальная сфера отделена от видимого мира материальной и зримой границей: «Н(е)бо н(е)б(е)съ, на нем же пр(њ)ст(о)лъ б(о)жий, то н(е)бо огнено, а сие видимое, г(лаго)лется твердь быти; под 
тьм н(е)бом анг(е)льское ликостояние и служение бываеть к б(о)гу» [Аввакум 1975: 98]. В этом пассаже Аввакум ссылается на «Гранограф», хотя в в основном тексте вводной космологическо-космогонической части «Хронографа русского» редакции 1512 г. высшее небо представлено не как огненное, но как светоносное [Русский хронограф 1911: 21]. Возможно, Аввакум имеет в виду «Палею Толковую», где отдельно объясняется огненная природа высшего неба [Палея Толковая 2002: 103-104], или же имеется в виду компиляция, предваряющая вторую разновидность редакции «Хронографа» 1620 г., где проявляется представление об огненном небе, почерпнутое в том числе из «Книги Еноха» и «Луцидариуса» [Унд728: 23об., 29об.], текстов, хорошо Аввакуму знакомых. Аввакум не развивает характерную для апокрифов идею о многоярусности небес, ограничиваясь лишь разделением духовного, огненного неба и плотского, водного по своей структуре уровня, в чем прослеживается влияние «Палеи Толковой», где также идея о многоуровневости небесных сфер не поддерживается [Мильков 2009b: 161]. Любопытен тот факт, что Аввакум, помещая «под тем небом» ангельские силы, относит их к сфере материальной, а не к ноуменальной. Их положение исключительно служебное, какой-либо индивидуальности они лишены, не заимствуется даже приведенное в «Палее» [Палея Толковая 2002: 17] и «Хронографе» [Русский хронограф 1911: 21] разделение ангелов по их функции (ангелы облаков, тумана, града, льда, бури и др.).

Видимое небо, согласно Аввакуму, было сотворено из воды как твердая перегородка: «И разлучи б(о)гъ между водою и водою и рече: “Да будет твердь!”[...] Слово - и дьло въскорь: от тое же воды згустилося, его же видим, н(е)бо» [Аввакум 1975: 99]. Водной структуре неба в «Снискании и собрании» не приписывается охлаждающей защитной функции, предохраняющей Землю от небесного жара, характерной для палейного повествования и отраженного в «Хронографе» [Палея Толковая 2002: 19; Русский хронограф 1911: 22]. Аввакум здесь лишь говорит о размещении половины всей изначальной воды, удерживаемой божественным повелением, на тверди: «[Т]ам половина воды, яко на полатя $x$, лежитъ и николи к нам не сходи $m$, токмо в пото $[. .$.$] » [Аввакум$ 1975: 99].

Сложно определить, является ли система Аввакума плоскостно-комарной или геоцентрической. С одной стороны, в текстах нигде не говорится прямо, что Земля плоская, с другой стороны, тяготение Аввакума к текстам антиохийской традиции может указывать именно на плоскостной характер Земли. То, что Земля «лежит» на воде, а не на китах (как указано в «Беседе трех святителей»), может свидетельствовать о ее 
плоскостном характере, однако Аввакум при этом ссылается на Иоанна Дамаскина, стоявшего на позициях геоцентризма и поддерживавшего представление о сферической форме Земли [Аввакум 1975: 99; Мильков 2008b: 43]. Распределение Солнца и Луны в «область дня» и «область ночи» также отсылает к плоскостно-комарной системе. В более позднем по отношению к «Снисканию и собранию» тексте Аввакума - послании Симеону, Ксении Ивановне и Александре Григорьевне (1678-1679) проявляется уже геоцентрическая картина, где можно наблюдать представление о тверди как о сфере, вращающейся вокруг Земли. Сферическая форма самой Земли, однако, не постулируется:

Небо сие видимое распростерто, кругом грядый над нами по повелению хитреца-Бога, еже повеле исперва: «небо, вертися скоро, звезды, теките борзо, и друг другу не препинайте». На нем же воды недвижимы пребывают, а твердь под водами в посолонь кругом грядый. Звезды же под ним отлучене, разлучне со своими круги летяще под землю и по малой тверди под землею шедше, паки на око ю восходят, коловратствуя непрестанно [Аввакум 1960: 264].

Поскольку Аввакум использовал «Палею Толковую» и «Хронограф» в качестве отправной точки для представлений о космоустроении, возможно, что описывается земля, которая имеет округлую форму и покоится в центре мирового океана, однако прямого указания на форму земной поверхности в «Снискании и собрании» нет. Система Аввакума несет в себе черты того эклектизма, которым отмечен и текст «Палеи Толковой» [Мильков 2009а: 12].

Структурообразующим элементом для тварного мира является вода, мы встречаем ее на нескольких уровнях - это твердь, земля, которая, по словам Аввакума, «соестествена воде» и одновременно окружена ею со всех сторон [Аввакум 1975: 98-99]. Классическое противопоставление огня и воды, таким образом, получает новое наполнение. Огонь - признак мира ноуменального, тогда как вода - символ тварности мира. Аввакум в своих рассуждениях полагается не только на богословские догмы, но и на житейский опыт и элементарную логику, говоря, что «землю [Бог] взял от воды, а не от пьны, потому и земля тяжела, а пьна - лехкое дъло» [Ibid.: 98]. Небесные тела при этом «имеют сродство» огненному небу и украшают небо видимое.

Небесные тела перечисляются Аввакумом в следующем порядке: Аррис (Марс), Ермис (Меркурий), Крон (Сатурн), Артемида (Венера), Солнце, Луна, остальные звезды. Этот порядок значительно отличается от принятого в геоцентрической традиции, где под областью звездного неба последовательно располагаются Сатурн, Юпитер, Марс, Солнце, Венера, Меркурий, Луна и потом центральная Земля. Аввакум нарушает 
принятый порядок перечисления светил, пропускает Юпитер, а вместо «Афродиты» указана «Артемида» ${ }^{6}$ В одном из его основных источников - «Палее Толковой» - светила септенера располагаются следующим образом: Марс - Меркурий - Юпитер - Солнце - Венера - Сатурн - Луна [Палея Толковая 2002: 51; Барс620: 232]); в основном тексте «Хронографа» светила упоминаются в порядке, унаследованном из геоцентрической системы: Сатурн - Юпитер - Марс - Солнце - Венера Меркурий - Луна [Русский хронограф 1911: 28], а в упоминаемой нами космологической компиляции из «Хронографа» расположение также нарушено: Солнце - Марс - Меркурий - Юпитер - Венера - Сатурн Луна [Унд728: 28]. Однако Аввакум существенным образом нарушает также хронологию событий Книги Бытие (Быт 1:16-19), согласно которой светила были созданы на четвертый день творения, и описывает хронологию следующим образом:

И в первый д(е)нь б(о)гъ звъзду сотворил и положил на тверди н(е)б(е) сней, - ей же имя Аррисъ; а во вторый д(е)нь звъзду сотворилъ, - ей же имя Ермис; а в третей д(е)нь Кронъ; а в четвертый Артемиду, и солнце в той же д(е)нь сотворил; а в пятый д(е)нь м(њ)с(я)цъ сотворилъ. И н(е)бо звЊздами украся, солнце положил во область дни, а луну - во область нощи [Аввакум 1975: 100].

Чем вызвано такое принципиальное нарушение, определить сложно, хотя и напрашивается упрощенное объяснение, что Аввакум, будучи в ссылке в Пустозерске, был вынужден полагаться на память, а потому мог просто допустить ошибку. Это могло бы пролить свет на пропуск Юпитера и нетипичное обозначение Венеры. Что же касается порядка творения, то нельзя исключить и влияние типичной для апокрифических текстов связи небесных тел с определенными днями недели [Турилов, Чернецов 1985: 320-321], и если дни недели соответствуют дням творения, то и светила могли создаваться постепенно, а не в определенный день.

Мир земной в понимании Аввакума максимально упрощен, однако в его модели благодаря всепронизанности мира Божеством укрепляется связь с духовными областями реальности. Коммуникация Бога и человека не прерывается каким-либо числом перегородок, кроме тверди, между сферой пребывания Божества и сферой человека воздвигается лишь одна граница, и субъективно человек в системе Аввакума оказывается ближе к трансцендентности, чем человек в схоластической адаптации геоцентрической модели универсума, где между эмпиреем и подлунным миром находится еще и некоторое число (от восьми до

6 В сборнике Дружинина указана как Афродита, так и Артемида [Аввакум 1975: 182]. 
десяти) небесных сфер - пусть и не плотных, но все же тел [Chadaeva 2018: 23]. В мире Аввакума космологическая привязанность условна, гораздо важнее оказывается ориентация человека относительно божественного света [Герасимова 2012: 209]. И потому более подробное миропознание, направленное на мир физический, Аввакум осуждает, как попытки постичь Божий промысел, проникнуть в тайны мироздания: «Оставя промыслъ творца своего да дьяволу работаете, невродяне, безчинники [...] А вы, разумные свиньи, лице н(е)бу и земли измъряете, а времени своего не искушаете...» [Аввакум 1975: 110].

\section{4. Человек и грех}

Итак, человек - единственное творение Бога, созданное не вербально, а «боголепными руками». А. К. Бороздин, одним из первых серьезно занимавшийся исследованием творчества Аввакума, продемонстрировал связь представлений о творении протопопа со «Словом о вочеловечении» Иоанна Златоуста [Бороздин 1900: 226]. На представления о сотворении человека оказали влияние и апокрифы [Сарафанова 1962: 334; Панченко 1982: 150-151]. Бог создает человека из земли как «скудел(ь)никъ скуделу», его можно сравнить с горшечником, обрабатывающем глину [Аввакум 1975: 102]. «Руки» Божества, по Аввакуму, следует понимать не буквально, а как две исходящие от Бога-Отца ипостаси - Сына и Духа, где «един сотворил, а другий и совершил повельниемъ отчимъ» [Ibid.: 103]. Таким образом, в сотворении человека задействованы все ипостаси Троицы. Уже в момент сотворения Адам не является лишь самим собой, конкретным Адамом, в нем проглядывают и черты других людей, он становится предзнаменованием истории. Адам в тексте Аввакума - образ и конкретный, и символический. Адам-символ - это прообраз апостолов Петра и Павла - хранителя ключа от рая и проповедника веры, двух принципов спасения, веры (ключ) и дел (проповедь): «И в то время провидъ г(о)с(по)дь во Адамъ ап(о)ст(о)лов Петра и Павла: Петру ключа ц(а)рства н(е)б(е)снаго вверяема, Павлу же бл(а)гоч(е)стие проповьдающе» [Ibid.]. При этом ключ к их появлению - Христос: «[Б]ыша сии апостоли, егда с(ы)нъ б(о)жий воч(е)л(о)вьчился» [Ibid.].

А. М. Панченко, полемизируя с П. Хант, утверждавшей, что Аввакум в своем знаменитом видении из пятой челобитной отождествляет себя с Христом [Хант 1977: 82], полагал, что Аввакум в первую очередь отождествляет себя с Адамом, т. е. человеком вообще [Панченко 1996: 47]. Н. М. Герасимова убедительно показала, что ближайший для Аввакума образец и точка соотнесения - не Христос и не Адам, а апостол Павел [Герасимова 2012: 247]. На наш взгляд, соотнесение Аввакумом 
себя с персонажами священной истории не однозначно, и параллели могут прослеживаться по всем трем основным направлениям, поскольку именно сотворение Адама предопределило вочеловечение Сына Божия, а Христос, вочеловечившись, примирил разрыв между сферой трансцендентного и человеком и стал человеком абсолютным. В результате вочеловечения стала возможна замена Адама в его роли универсального человека тем, кто несет свет Христа, - апостолом Павлом. В «человечности» у Аввакума можно наблюдать сразу два полюса - это способность к прямой, непосредственной коммуникации с Богом и приближение к трансцендентности, это вочеловечевшийся Христос и несущие свет его апостолы и, с другой стороны, самые низменные, греховные черты, свойственные как библейским персонажам (что характерно - старозаветным, т. е. еще не очищенным светом Христа), так и грешным современникам Аввакума.

Первый человек, Адам, лишен в представлении Аввакума каких-либо специфических характерных черт вплоть до момента грехопадения. Его индивидуальность, как и прямая речь, проявляется лишь после того, как он вкусил запретный плод (согласно Аввакуму, это был виноград, т. е. прообраз алкоголя) [Аввакум 1975: 103-104]. Опьянение, как и последовавшее за ним похмелье, описано Аввакумом характерным для него разговорным экспрессивным языком, к цитатам реплик Адама из Книги Бытие добавляется и вольная интерпретация, напр., Еву Адам в запальчивости называет «дурой». В «Снискании и собрании» Адам после грехопадения предстает перед читателем как собирательный образ пьяницы, обвиняющего в своей слабости кого угодно, только не себя. Он встает наравне с современниками Аввакума, как с невоздержанными в питии, так и более серьезными грешниками - блудниками, прелюбодеями, татями, разбойниками и злодеями [Ibid.: 105]. Повествование в момент грехопадения распадается на два временных плана: Адам грешит, страдает от похмелья, лжет и выкручивается одновременно с «нынешними» грешниками. Сравнение Адама и Евы с современными Аввакуму грешниками становится пояснением и актуализацией проблематики как минувшего, так и настоящего, приемом оживления и вывода героев из статики [Елеонская 1978: 131]. То же самое происходит и позже - когда совершает убийство Каин, когда Нимрод пытается проникнуть в тайны будущего, и вместе с ними совершают грехи «безчинники» и «невродяне» во времена Аввакума [Аввакум 1975: 107, 110]. Грехопадение имеет сразу три временных плана - прошлое, настоящее и будущее: «Узнаем тогда, какъ погонят от рая, яко и Адама со Еввою за несоблюдение заповъди» [Ibid.: 105]. Преступление Адама продолжает происходить и неминуемо случится в будущем: «Аще и н(ы)нь дре- 
во райское обрящется [...], вси не устоятъ, но падше поклонятся пред нимъ» [Ibid: 102].

Кроме того, внимания заслуживает тот факт, что у Аввакума на протяжении всего повествования о событиях библейской истории практически отсутствует фигура Сатаны или дьявола, он выступает не самостоятельным участником происходящего, а скорее фоновым элементом. Текст Аввакума не повествует об отпадении Сатаны, дьявол появляется в момент грехопадения человека как бы из ниоткуда, внезапно:

И позавидъ дьяволъ чести и славњ Адамли, вниде в лучшаго звъря - во змию, и оболга б(о)га ко Адаму, рече: «Зависливъ б(о)гъ, Адаме, не хощет вас таковы $x$ быт(ь), каков сам. Аще вкусите от древа, от него же ясти заповњда вам, и вы будете яко бози» [Аввакум 1975: 103].

Дьявол у Аввакума ближе скорее к бесу, вредителю-завистнику, чем к грандиозной фигуре воплощенного зла. И хотя он имеет некое влияние на людей, грешного человека не оправдывает вмешательство враждебной силы, ответственность целиком и полностью лежит на человеке: «[Все] другъ на друга переводя $m$, а все заодно своровали» [Аввакум 1975: 105]. В конце времен дьявола, его приспешников и грешников ожидает одинаковая судьба, никак не иерархизированная: «[Т]амо и дьяволъ будет $з$ бъсы осужденъ, тамо с ними будутъ и вси отступники, и мучени будутъ во въки вькомъ» [Ibid.: 101].

Аввакум вообще не затрагивает в своем тексте проблематику взаимоотношения полов и полового акта как проявления греховности. Грехопадение в его понимании связано именно с пьянством, а не с блудом: Адам познает Еву лишь после изгнания из рая. Но именно грехопадение становится причиной проявления телесности в самых низменных ее проявлениях - боль, рвота, недержание. Адам до греха схематичен, как и рай, в котором он живет, и обретает тленную и подверженную слабостям плоть, вкусив от древа познания. При этом грехопадение человечества не ограничивается лишь четырехкратным грехом Адама (нарушение запрета, пьянство, ложь, попытка «перевести» свой грех на другого), но постепенно усугубляется уже при потомках праотца. За братоубийством Каина следует волхование (до потопа), неуважение к родителям (Хам), попытка проникнуть в тайны будущего (Нимрод). Акцентирование именно этих прегрешений в сочинении, написанном Аввакумом для своих последователей, демонстрирует нам шкалу антиценностей Аввакума, посылающего ясное сообщение своим ученикам о тех слабостях, которых им следует остерегаться. 


\section{5. Рай и его потеря}

Создав землю, Бог занялся ее украшением, в описании которого проявилось стремление Аввакума к поэтизации действительности. Сначала автор наметил цветовой фон: «И израстоша былия прекрасная, травы цвътныя разными цвђты: червонныя, зъленыя, лазоревыя, бълыя, голубыя [...]» [Аввакум 1975: 101]. Далее к цветовому фону добавляются образы деревьев: «Тако же и древа израстоша: кипариси и пьвги, и кедри, мирсины и черничие, масличие и виноградие, и финики и иное садовие [...]» [Ibid.]. Аввакум оформляет картину мира как живописец: деревья задают вертикаль, к которой добавляется горизонталь рек, протекших среди гор: «И реки среди гор протекоша, и источники водныя» [Ibid.]. Далее статичную картину пейзажа приводят в движение живые существа - созданные из земли животные, созданные из воды птицы, а также пресмыкающиеся и насекомые. В этом фрагменте представлено владение словом, которое в творчестве Аввакума используется как инструмент визуализации. Создаваемая им картина начинается с определения цветовой палитры, далее вертикаль и горизонталь создают перспективу, и в последнюю очередь добавляется динамичный элемент - живые создания. Заключительным актом творения физического мира, предваряющим появление человека, становится создание рая.

Рай в «Снискании и собрании» делится на две части. Первая - это «Рай Едемский», который был создан в самом начале существования этого мира, а в будущем он распространится по всей земле, а вторая «град святый Сион» - будет находиться на воздухе [Аввакум 1975: 100]. Личного, камерного рая, описываемого Аввакумом в «Житии» [Демин 1998: 725], в «Снискании и собрании» нет.

Локализация рая до Второго пришествия закрепляется за конкретным местом: «Посем насадил рай во Едеме, на востоце» [Аввакум 1975: 101]. Рай не подвержен процессам старения и тления и одновременно является физическим и духовным местом: «[А]ще и на земль рай, но посредъ плотна и д(у)х(о)внаго жития устроенъ» [Аввакум 1975: 101]. Рай, как и в апокрифических произведениях [Демин 1998: 699], не исчез в результате грехопадения, он возвышается над всем остальным миром и временно запечатан [Аввакум 1975: 102]. Тем не менее полностью связь с Эдемом не прервалась даже после запечатывания, подтверждением чего может служить заимствованный Аввакумом из «Пролога» фрагмент предания, где молящейся перед своим успением Богородице ангел приносит финиковую ветвь именно из физического рая [Аввакум 1975: 102; Сарафанова 1962: 337]. Возможность физического контакта с запечатанным Эдемом сохраняется и далее, так как части ветви разделяют между собой после успения апостолы. 
Сам момент потери рая описан как событие, потрясшее не только человека, но и весь физический мир. Небесные тела, земля и вода в момент изгнания Адама и Евы из рая наделяются определенными антропоморфными чертами, когда к ним применяются категории модальности:

Солнце сожещи ево хотьло, луна и звظзды примрачилис(ь), н(е)бо простерто не восхотьло стояти, земля в воды хощетъ побъжати, море ис предълъ выступит (ь) тщится и потопит (ь) законопреступны $x$, садовие плодовитое увядают [...] анг(е)ли на н(е)б(е)сьхъ плачутъ, и вся твар (ь) с ними рыдаетъ: не восхотьли падшему служити [Аввакум 1975: 105-106].

Тем не менее Бог приказал своим творениям стерпеть и не выступать из своих пределов, т. е. не нарушать миропорядок, «дондеже не обновлю падший мой образ». Грехопадение - тот момент, когда качественно меняется не только течение времени, но и состояние материи: «[В] ся твар (ь) совоздыхает, и збользнуетъ с нами, и желаетъ нашего дне, когда с(ы)ны б(о)жия будем» [Аввакум 1975: 102].

Потеря рая, однако, не ограничена лишь одной историей Адама и Евы. Потеря постоянно актуализируется, так как каждый человек в любой момент жизни может повторить грех Адама. Потому и не стоит обвинять Адама во всех бедах человечества: «Что на Адама пеня $m($ ()? Мы и сами в том же сластолюбии погрязли» [Аввакум 1975: 106]. Существует и оборотная сторона: рай потерян не безвозвратно, и уже в настоящем у человека появляется возможность его вернуть: «Адам сластолюбием [рай] заключил, мы ево взыщем постомъ и м(о)л(и)твою, любовию и м(и)л(о)ст(ы)нею, слезами и покаяниемъ, и прочими добродытел(ь)ми с терпьниемъ» [Ibid.: 102]. Аввакум, таким образом, уверен в обретении рая и избранности для себя и своих последователей.

Рассказ о первых событиях Книги Бытие до истории Каина и Авеля Аввакум завершает выводом о том, что мир, сотворенный ради человека, - это общий дом, где нет места ни вражде, ни социальным различиям: «[Г](о)с(по)дь землю общу сотворил и н(е)бомъ, яко камарю, покрыл. Д(е)нь равно всъмъ свђтитъ, солнце також сияет равно, чтоб друг друга жили любя, яко во едином дому» [Аввакум 1975: 106-107]. Здесь мы можем наблюдать отношение Аввакума к принципу иерархии: в его представлении иерархическая система касается исключительно сферы ноуменальной, а не феноменальной. На физическом, событийном уровне вся иерархия едва ли не анархически снимается, так как Бог «землю общу сотворил», а связь с трансцендентной вертикальной осью бытия не ограничивается социальным статусом, заслугами или достижениями. Каждому существу доступна возможность прикоснуться 
к трансцендентности в любой момент жизни в случае, если оно обратится к истинной вере. Однако человек, нарушая заветы, становится динамическим элементом в статичной картине сотворенного мира. Неслучайно именно после грехопадения начинает отсчитываться хронология: время, проведенное Адамом в Эдеме, относительно и не событийно, здесь неважно, какова была длительность безгрешного пребывания Адама в раю7, динамика появляется после того, как Ева и Адам нарушают запрет. В «Снискании и собрании» этот момент библейского сюжета становится переломным, когда автор переходит от повествовательно-описательной части к историческо-событийной.

\section{6. История и ее смысл}

Божественное всеприсутствие, как уже было отмечено, проявляет себя не только в пространственной, но и во временной плоскости, где движение времени является линейным следованием событий от сотворения мира до двух ключевых моментов истории - Первого и Второго Пришествия. Течение времени в «Снискании и собрании» имеет сразу три измерения. В первую очередь, это движение линейное, т. е. ход человеческой истории. Далее возникает время циклическое, т. е. замыкание истории в сразу двух кульминационных точках развития - вочеловечении Христа, обновившем человечество, и Втором пришествии, обновившем весь мир, который, очистившись, был выведен из линейного событийного движения истории. Третий временной уровень - «многие века» Бога, вынесенные вне человеческого цикла. Как отметила П. Хант, в «Снискании и собрании» бок о бок стоят описание сотворения мира и его конца [Hunt 1975-1976: 162]. Описывая сотворение неба и светил, Аввакум сразу же переходит ко Второму пришествию:

А во второе пришествие свое г(о)с(по)дь всю твар(ь) видимую сию переновитъ, сирьчь переполощетъ негасимым огнем, и буде $m$ н (е)бо ново и земля нова, и людей-тъх же переновитъ; воскреснутъ вси, и комуждо по достоянию и мъсто укажетъ г(о)с(по)дь во въки безконечныя [Аввакум 1975: 100].

В физическом отношении мир Аввакума практически статичен, динамика идет по двум направлениям: это вертикальное движение мира духовного и ощущение динамизма в области исторического процесса, ускоряющегося по направлению к концу времен. Это мир, живущий в ожидании перерождения, и его стабильность - лишь иллюзия. Движение в нем неравномерно: если вертикальное духовное движение постоянно, то горизонтальная линия исторического процесса ускоряется, и

7 Сто лет, три года или шесть часов [Аввакум 1975: 103]. 
точка опоры может быть найдена только в трансцендентной вечности. Повествование ускоряется с каждым следующим персонажем библейской истории: если события грехопадения, убийства Авеля Каином и потоп описаны относительно подробно, то после Вавилонского столпотворения имена мелькают одно за другим, выпадают целые куски («О том не писал, какъ Моисью закон дан бысть [...]» [Аввакум 1975: 112], история спешит завершиться на своем первом этапе - вочеловечении Христа, давшего возможность быть и внутри, и вне ее, приблизиться ко времени трансцендентному, стать наблюдателем времени. В «Снискании и собрании» Адам практически незаметно исчезает из повествования, похоронив Авеля и «родив» двух дочерей для Каина и Сифа. Мы так и не узнаем, сколько лет он прожил и как скончался. Это уже не важно, так как для современности имеют значения лишь те события, которые связаны как с вечностью, т. е. с божественным замыслом, общим потоком истории, ведущим к ее отмене, так и с каждой точкой настоящего.

Возможность смотреть на историю извне имеют три субъекта: это всеведающий Бог, автор и читатель. Бог, находящийся в центре системы координат Аввакума, он сам и его последователи включены в круг спасения [Герасимова 2012: 215]. Именно они видят ясно смысл истории - ее отмену, переход на иной временной или вневременной уровень. Как отмечала С. Матхаузерова [1976: 125], анализировавшая временные категории у Аввакума, в поле его зрения «входили и действия, измеряемые человеческим временем, и действия, относящиеся к категории вечности». В «Снискании и собрании» это стремление представлено на повествовательном уровне исключительно объемно. Описывая грех Адама, Аввакум говорит о «нынешних» пьяницах, говоря об убийстве Авеля, он упоминает современные ему распри («мы же [...] яко псы и яко котки, друг на друга ворчимъ и прыщем, яко козлы») [Аввакум 1975: 107], от вавилонского столпотворения и истории Нимрода он резко переходит к критике определений «добрых» и «злых» дней современными ему гадальщиками [Ibid.: 110]. Исторические события у него постоянно накладываются на восприятие актуальной действительности, и, несмотря на его желание, именно настоящее оказывается сильнее, постоянно стягивая на себя внимание автора, отвлекая его от вневременной вечности, к которой Аввакум стремился. Тем не менее весьма важными следует считать частые отсылки к «Хронографу» как к тексту, в котором представлена истинная для Аввакума картина истории, в отличие от «ложных» повествований, поскольку Аввакум стремится найти в истории универсальный ответ и руководство к миропониманию. Следует, впрочем, учитывать, что во второй половине XVII в. 
текст «Хронографа» дробится, возникают многочисленные хронографические компиляции, так называемые хронографы особого состава, и он теряет характер систематического изображения истории [Творогов 1972: 226]. Это знаменует новый период в понимании истории и ее смысла.

\section{7. Автор и читатель}

Фигура автора в его отношении к Богу появляется в самом начале текста «Снискания и собрания», когда цитируется Евангелие от Иоанна, фрагмент, где Иисус обращается к своим ученикам, говоря об истинности своих утверждений и о том, что восприятие божественного слова указывает на связь с Богом-отцом, тогда как рецепция ложной информации указывает на генетическую связь слушателя с диаволом [Ин 8:42-44; Аввакум 1975: 92]. Эта цитата задает магистральную линию для прочтения всего текста, раскрывает позицию автора - транслятора истины, сопричастного трансцендентности. Смелость Аввакума, неоднократно бравшего на себя роль носителя абсолютной правды и описывавшего свое слияние с Богом, много раз была отмечена исследователями [Хант 1977: 78; Мильков 2002: 24]. В тексте «Снискания и собрания» эта параллель не проводится прямо, сначала Аввакум обращается к читателю, призывая его «внимать г(о)с(по)дня речения» [Аввакум 1975: 92], позже появляется и самостоятельное авторское «я», где Аввакум ставит себя вровень с апостолом Павлом: «Слушай, мы с Павлом отвђщаемъ ти» [Ibid.: 93]. Позже это «мы» может быть перенесено и на сподвижника Аввакума, на его читателя, причем тоже человека грешного: «Мы же речем: “О сластолюбие Адамле и пиръ пьяной! [...] Мы и сами в том же сластолюбии погрязли” [Ibid.: 106].

В «Снискании и собрании» не только роль автора исключительно ярко выражена. Говоря от первого лица, он устанавливает контакт с читателем. Даже раньше, чем подчеркнутое авторское «я», в тексте возникает «ты», образ адресата, «слышателя», не ученого и не студента, но последователя, ученика, заблудшего и запутавшегося, которому предоставляются как информация, так и ссылки на авторитетные тексты, которые должны войти в круг его чтения. Это не «возлюбленный слышатель» барочных гомилий, выступающий скорее отвлеченным, абстрактным реципиентом, но вполне конкретный и живой адресат, знакомый с конкретными источниками. И автор здесь выступает с позиций не ученого, не книжника: его авторитет зиждется на вере, а не на фактах. Он не сверяет и не связывает воедино целостную картину бытия, в цитировании полагается как на текст, так и на память, но твердо уверен, что все предоставляемые им сведения истинны. Сила 
этой веры проявляется и в том, что Аввакум, стремясь передать свою убежденность читателю, постоянно употребляет повелительное наклонение, причем задействует все возможные способы постижения истины - «виждь», «зри», «чти», «внимай», «слушай», «смотри», «разумей». Он говорит не о знании, но о восприятии и принятии информации, что разительно отличается от образовательного пафоса его современников - барочных авторов, в первую очередь Симеона Полоцкого. Миром и божественной мудростью следует восхищаться, смиренно постигать ее «в сопребывании с мудрыми», а не изучать, усваивать или измерять [Николаев 2000: 75].

Коммуникативный аспект в тексте реализуется в том числе посредством включения значительного количества риторических вопросов: «Кто въсть, что есть б(о)гъ и гдъ ему обител(ь)?»; «Разумъеш(ь) ли, слышателю, гдњ писание тартаръ возвьщаетъ?»; «А затьмъ что? Не вышереченныя ли муки?» и др. [Аввакум 1975: 93, 101, 105]. И если вопросительные формулы в «Житии» в основном подготавливают введение новой темы или побуждают слушателя к признанию непреложности и неотвратимости описываемых событий, а также обостряют наиболее трагические эпизоды [Виноградов 1980: 33-34], то в «Снискании и собрании» вопросы играют как акцентирующую роль, так и роль установки более близкого контакта с читателем.

В тексте «Снискания и собрания», в отличие от «Жития», отсутствует центральный герой или объект описания. Это не Адам, он лишь одно из лиц, один из «твари». Здесь нет главного героя-участника описываемых событий, но присутствуют три основных участника на уровне текста - Бог, автор и адресат. О Боге и его делах постоянно идет разговор, и, поскольку Бог всеведущ и всеприсутствующ, он также становится участником этого разговора. Он вступает в коммуникацию с человеком на протяжении всего текста - являясь Аврааму, Моисею, Иакову, пророкам Исайе, Иезекилю и Даниилу, Иоанну Богослову [Аввакум 1975: 93-96, 111], говорит с Адамом [Ibid.: 104-105], Каином [Ibid.: 107], Ноем [Ibid.: 108]. Аввакум же прямо и непосредственно диктует читателю как способ интерпретации библейского текста, так и «список дополнительной литературы», а также призывает задуматься над собственными прегрешениями. Читатель Аввакума - это ученик и последователь, такой же грешный человек, как и праотец Адам, имеющий, впрочем, возможность заслужить спасение, причем в самом ближайшем времени.

\section{8. Два «Потерянных рая»: Дж. Мильтон и Аввакум}

Самое заметное место в череде западноевропейских писателей и поэтов, отразивших в своем творчестве как кризисный характер XVII в., 
так и проблематику нового определения человека и его места в истории, занимает Дж. Мильтон с его эпической поэмой «Потерянный рай». В поэме соединяются обращение к еврейской традиции мидрашей - комментариям к тексту Священного Писания [Werman 1995: 42-74; Shoulson 2001: 10-18], тесная связь с наследием античности, реминисценции из Данте, Спенсера и Тассо [Porter 1993: 84], а библейская история рассматривается со множества точек зрения - как теодицея, трагическая история падения Сатаны, проблема времени, пространства, предопределения и др. В «Потерянном рае» есть и творческая переработка английских событий XVII в., и проблематика переосмысления представлений о космосе [Sarkar 2012: 116, 148]. При всей удаленности «Потерянного рая» Мильтона и «Снискания и собрания» Аввакума друг от друга, было бы интересно сопоставить сочинения, интерпретирующие библейскую историю и написанные практически одновременно («Потерянный рай», написанный в 1658-1663 гг., был издан в 1667 г., тогда как «Снискание и собрание» датируется 1672 гг.). Учитывая факт, что уже проводились типологические сравнения «Жития» Аввакума с другими произведениями, не связанными с ним генетически, включая роман М. де Сервантеса «Хитроумный идальго Дон Кихот Ламанчский» и «Записки» Я. Х. Пасека [Николаев 2003: 35], сопоставление интерпретации Аввакумом Книги Бытие с текстом Мильтона нам представляется оправданным и заслуживающим внимания. «Потерянный рай» Мильтона - это эпическая и многоуровневая панорама, где на позиции наблюдателей находятся как автор, так и читатель, наблюдающие свершение истории, причем Мильтон проявляет ту степень переосмысления и вымысла в отношении библейского текста, какая была бы совершенно немыслима для Аввакума. Наряду с таким текстом «Снискание и собрание», локальный коммуникативный акт, выглядит более чем скромно. Однако, несмотря на то что тексты разительно отличаются друг от друга по целому ряду параметров, включая форму, жанр, объем, круг источников, замысел, их объединяет тема - интерпретация первых событий в истории, грехопадения, роль человека и его взаимоотношения с Творцом.

На оба текста можно смотреть как на инструкции для чтения библейского текста, но если Аввакум директивен в интерпретации Священного Писания и «списке рекомендуемой литературы» (см. выше), то у Мильтона побуждение к чтению и обогащению знаний происходит сквозь множественные аллюзии и отсылки [Rajan 1962: 18], включающие в первую очередь тексты не религиозные, а принадлежащие к общеевропейскому и специфически английскому культурному наследию. С другой стороны, современность в соотношении со священной историей 
в тексте Аввакума отражается напрямую, тогда как в «Потерянном рае» она скрывается за многоуровневым рядом аллюзий.

Для Мильтона, как и для Аввакума, всемогущий и всевидящий Бог - центр миропонимания, однако магистральная тема, связанная с божеством, разительно отличается. У Мильтона это теодицея, оправдание существования зла и греха («justify the ways of God to men» [Milton 1892: 6]), тогда как для Аввакума само появление подобной мысли в принципе невозможно. Отличается и понимание творения и его смысла: у Мильтона это отчасти сотворение de deo, не ex nihilo [Lehnhof 2004: 15], т. е. все существующее - это продолжение Бога, его сущности, в то время как Аввакум либо представляет сотворение из света, либо постулирует вербальный характер творения.

Мильтона, как и Аввакума, волновали вопросы предопределения судьбы человечества и жертвы Христа, на это направлена обширная рефлексия в кн. III «Потерянного рая» [Milton 1892: 43-50]. В поэме Мильтона предопределение хода истории происходит в тот момент, когда поверженный Сатана, стремясь отомстить за свое падение, летит к этому миру (т. е. новому, сотворенному Богом) [Milton 1892: 43-50], причем предопределение происходит в два этапа: когда Бог предвидит падение («For Man will hearken to his glozing lies, / And easily transgress the sole command [...] so will fall / He and his faithless progeny» [Milton 1892: 44]) и когда Христос предлагает себя в жертву во имя спасения человечества («Me for him, life for life, I offer» [Milton 1892: 47]). У Аввакума же эсхатологический план оформляется в момент принятия Богом решения о сотворении человека, и если грехопадение предвидит Сын («Сотворим, отче, и преступит бо» [Аввакум 1975: 102]), то решение о вочеловечении в тексте Аввакума принимает, наоборот, Бог-Отец, а Сын покоряется его воле. Таким образом, если в интерпретации предопределения у Мильтона движущей силой истории выступают Сатана и Христос, то в тексте Аввакума решающая роль отведена Богу-Отцу и самому человеку, сотворение которого предопределяет действия одной из божественных ипостасей, а грех заложен изначально.

Ключевой для «Потерянного рая» является фигура Сатаны, играющего роль главного героя на протяжении первых двух книг, наиболее сложного, неоднозначного персонажа [Verbart 1995: 45]. Рай в поэме Мильтона потерян дважды, впервые это свержение падшего ангела (кн. I), причем бунт его совершается как осознанный выбор, целью которого была не только жажда власти, но и сохранение собственной идентичности («What matters where, if I be still the same, / And what I should be, all but less than He [...], We shall be free [...] Here we may reign secure» [Milton 1892: 10-11]). Грехопадение Адама, именно из-за мести поверженного ангела 
и слабости человека, происходит уже позже. У Аввакума же, как было отмечено выше, фигура персонифицированной тьмы в повествовании отсутствует, а ответственность за грех лежит целиком и полностью на человеке, причем грех этот - не любопытство даже, а невоздержание [Аввакум 1975: 104]. Для Аввакума внешним проявлением греха становится пьянство, и практически никакие аспекты межполовых отношений в контексте понимания сути греха Аввакума не интересуют, тогда как в тексте Мильтона особо подчеркивается сексуальный аспект греховности. Существенное внимание Мильтон уделяет проблематике взаимоотношения полов, подробно описывая как их «чистую», так и «греховную» формы, причем как в физическом плане, так и в психологическом аспекте (кн. IV, V, IX).

Мильтон детально описывает характер и мотивацию поступков женского персонажа - Евы, которая Аввакумом упоминается лишь вскользь, не говоря уже о разработке характера Адама, тогда как в тексте Аввакума первый человек схематизирован и выступает прообразом будущего человечества в целом. Вообще характер, личность для Мильтона - центральные объекты рефлексии, что проявляется и в несравнимо большей степени персонификации ноуменального мира. Так, подробно разрабатываются характеры не только павших ангелов, но и слуг Бога - архангелов Рафаила и Михаила, действующих вполне самостоятельно, Аввакум же в своем повествовании не уделяет бесплотным силам значительного внимания, придерживаясь канона Священного Писания.

Авторов роднит значительное внимание, уделяемое сотворению мира и его устройству. В поэме «Потерянный рай» читатель не становится непосредственным наблюдателем самого процесса творения, так как информация о мироустройстве передается через дополнительного рассказчика - архангела Рафаила (кн. VII и VIII). Аввакум же передает историю сотворения мира напрямую, ссылаясь на авторитетные для него тексты. При этом мир физический у Мильтона - лишь один из возможных, так как Бог создает его после падения Сатаны («I can repair / That detriment, if such it be to lose / Self-lost, and in a moment will create / Another world» [Milton 1892: 116]). У Аввакума же мир возникает как следствие возможности Божества вербализовать творение и деление миров наблюдается лишь на уровне мира небесного и земного, возникшего вследствие создания первого.

В системе Аввакума человек субъективно оказывается ближе к трансцендентности, чем в мире Мильтона, где первичную коммуникацию между Богом и Адамом осуществляет архангел Рафаил (кн. VVIII), а между сферой Эмпирея и Землей находится неопределенное 
количество сфер, причем человек стремится «навертеть циклов и эпициклов» («With Centric and Eccentric scribbeled o’er, / Cycle and Epicycle, Orb in Orb» [Milton 1892: 127]), хотя понимание всей этой структуры и того, что находится в ее центре, недоступно человеческому восприятию:

Whether the Sun, predominant in Heaven,

Rise on the Earth; or Earth rise on the Sun [...]

Solicit not thy thoughts with matters hid;

Leave them to God above; him serve, and fear!

[Milton 1892: 129].

Показательно, что в последнем утверждении Аввакум в своей своеобразной манере мог бы лишь поддержать Мильтона, осуждая попытки постичь Божий промысел. Близость человека к трансцендентности в тексте Аввакума при этом подчеркивается тем, что Бог говорит с человеком напрямую, тогда как у Мильтона он вступает в коммуникацию лишь с Христом или бесплотными силами, передающими Адаму божественное волеизъявление.

Мильтон в «Потерянном рае» дает своему герою Адаму возможность взглянуть на все течение истории в эсхатологической перспективе, завершающейся Вторым пришествием [кн. XI и XII; Milton 1892: 195-223]. У Адама Аввакума такой возможности нет, но читатель вместе с автором по сравнению с первым человеком имеют то преимущество, что точно так же могут посмотреть на историю извне, ожидая конца света. Эсхатологические аспекты, таким образом, присутствуют в обоих произведениях, отражающих тему потери рая, однако их реализация отличается.

Чувство потери проявляется в обоих произведениях, однако его острота значительно отличается. «Потерянный рай» пронизан отчаянием, ведь не только Адам теряет Эдем, но и Люцифер, сверженный с небес, пытается справиться с поражением и крушением надежд, и луч надежды брезжит лишь в кн. III, когда оформляется эсхатологическая перспектива, и в кн. XII, когда с ней знакомится Адам. У Аввакума же упоминание о Втором пришествии и новом мире появляется одновременно с идеей о сотворении мира и через все повествование проходит соотнесение событий как ветхозаветной истории, так и современности с возможностью спасения. Примечателен в этом смысле финал текстов: у Аввакума это утверждение эсхатологического плана во времени и вне его с помощью устойчивой формулы («Ему же слава со отцемъ и со с(вя)тым д(у)хом н(ы)нъ и пр(и)сно и во вьки въкомъ»), тогда как у Мильтона это начало пути, человеческой истории: 
The world was all before them, where to choose Their place of rest, and Providence their guide. They, hand in hand, with wandering steps and slow, Through Eden took their solitary way

$$
\text { [Milton 1892: 214]. }
$$

«Потерянный рай» Мильтона и восприятие той же потери у протопопа Аввакума в «Снискании и собрании» имеют несравнимо больше отличий, чем сходных мотивов. «Потерянный рай» обращен в первую очередь в прошлое, в глубину европейского культурного наследия, на повествовательном уровне - в историю отпадения Сатаны и грехопадения, а также сосредотачивается на теодицее и роли личности и характера, тогда как Аввакум фокусируется на настоящем и, возможно, близком эсхатологическом будущем. В понимании Аввакума история Книги Бытие должна служить схематичным руководством и напоминанием для его последователей, тогда как спектр вопросов, встающих в связи с трагедией человечества, у Мильтона намного шире. Сопоставление некоторых аспектов интерпретации библейской истории в «Потерянном рае» и «Снискании и собрании» помогают лучше понять актуальность и специфику ряда проблем в дискурсе исторического перелома раннего Нового времени в России.

\section{Заключение}

«Снискание и собрание» - это текст о трех составляющих - Боге, мире физическом (твари) и сотворении и последующем грехопадении человека. Основным субъектом в повествовании выступает Бог-Творец, превосходящий рамки творимого им мира как в пространственном, так и во временном отношении. Человек же становится субъектом в момент грехопадения, обретая собственный голос. Тем не менее в гораздо большей степени, чем с грехопадением Адама, «Снискание и собрание» связано с постоянной борьбой каждого конкретного идивидуума с грехом, и борьба эта включает все временные уровни - прошлое, настоящее и будущее. С одной стороны, текст Аввакума ориентируется на вечность, частью которой стал человек благодаря изначальному решению Бога. У Аввакума остро чувствуется именно настоящий момент, в котором присутствуют трое главных действующих лиц - Бог как абсолютная точка соотнесения, автор и читатель. Аввакум проживает историю грехопадения неоднократно, она происходит синхронно с его собственной, и, с другой стороны, точно так же синхронно идет сближение с трансцендентностью, возвращение рая. Вовлечение в текст автора и читателя осуществляется посредством соотнесения библейских персонажей с 
современными грешниками, при этом Аввакум с помощью языковых средств (императива и вопросительных предложений) поддерживает непрерывную коммуникацию с читателем, что делает текст «Снискания и собрания» интенсивным коммуникативным актом.

«Снискание и собрание» имеет структуру, зеркально противоположную картине мира, выстраиваемой в «Житии», где жизнь автора соотносится с библейскими сюжетами. Здесь события священной истории сопоставляются с современностью Аввакума. Потому эти два текста следует рассматривать как целое: в «Снискании и собрании» дается комментарий к онтологическим представлениям Аввакума и пониманию смысла истории как целого, тогда как «Житие» - отражение частного на фоне целого.

В тексте «Снискания и собрания» затронуты ключевые для мировосприятия Аввакума вопросы - это взаимоотношения Бога и человека, их коммуникация, представление о пространстве и времени, ход истории и его уровни, роль человека в истории, равенство людей перед Богом, а также восприятие священного текста и осмысление его информации. Сопоставление с «Потерянным раем» Мильтона помогает через призму интерпретации ветхозаветной истории акцентировать вопросы, ключевые для староверов на пороге Нового времени. Многие аспекты, включая творческую историю создания «Снискания и собрания» и его соотношение с другими текстами Аввакума, а также типологическое сопоставление с другими произведениями переломной эпохи, затрагивающими тему потери рая, еще требуют дополнительного осмысления.

\section{Сокращенные названия библиотек и древлехранилищ}

гим - Государственный исторический музей (Москва)

РГБ - Российская государственная библиотека (Москва)

\section{Библиограсрия}

Источники

Рукописи

Барс620

ГИМ, собр. Е. В. Барсова, № 620, Палея Толковая, по изд.: Мильков В. В., Полянский С.М. Космологические произведения в книжности Древней Руси. Часть II. Космологические тексты плоскостно-комарной традиции в древнерусской книжности, Санкт-Петербург, 2009, 165-300.

$\mathrm{У}_{\text {Hд}} 728$

РГБ, Собрание В. К. Ундольского, № 728, Хронограф, конец XVII - нач. XVIII в. 


\section{Издания}

Аввакум 1960

Послание Симеону, Ксении Ивановне и Александре Григорьевне, Житие протопопа Аввакума и другие его сочинения, Гудзий Н. К., ред., Москва, Ленинград 1960, 260-276.

\section{Аввакум 1975}

Снискание и собрание о Божестве и о твари и како созда Бог человека, Пустозерский сборник: автографы сочинений Аввакума и Епифания, Демкова Н. С., Дробленкова Н. Ф., Сазонова Л. И., ред., Ленинград, 1975, 92-112.

\section{Беседа трех святителей 1862}

Беседа трех святителей, Памятники старинной русской литературы, издаваемые Графом Григорием Кушелевым-Безбородко, Пыпин А. Н., ред., Вып. 3. Ложные и отреченные книги русской старины, собранные А.Н. Пыпиным. С.-Петербург, 1862, 169-178.

О небесной иерархии

А. И. Макаров, В.В. Мильков, А.А. Смирнова, Древнерусские Ареопагитики, Москва, 2002, 83-201, 223-286.

Палея Толковая

А. М. Камчатнов, подготовка др. рус. текста и перевода на совр. рус. язык, В. В. Мильков et al., коммент., Палея Толковая, Москва, 2002.

Русский хронограф 1911

Русский хронограф, Полное собрание русских летописей, 22, 1, С.-Петербург, 1911.

Milton 1892

Taylor, C., ed., The Poetical Works of John Milton. London, New York, 1892.

\section{Литература}

Бабалык 2011

Бабалык М. Г., Апокриф «Беседа трех святителей» в русской рукописной книжности XV$X X$ веков (диссертация на соискание ученой степени кандидата филологических наук, Петрозаводск, 2011).

Беляев 1913

Беляев И. Д., Хронограф третьей редакиии: Труд И. Д. Беляева, Москва, 1913.

Буланин 2016

Буланин Д. М., Утраченный рукописный источник русского хронографа (опыт реконструкции состава), Rossica Antiqua: Исследования и материалы, 13, 1-2, 2016, 99-136.

\section{Бороздин 1900}

Бороздин А. К., Очерк из истории умственной жизни русского общества в XVII веке, С.Петербург, 1900.

Виноградов 1980

Виноградов В. В., О задачах стилистики. Наблюдения над стилем Жития протопопа Аввакума, Idem, О языке художественной прозы, Москва, 1980, 3-41.

Герасимова 2012

Герасимова Н. М., Поэтика «Жития» Аввакума, Eadem, Прагматика текста: фольклор, литература, культура, С.-Петербург, 2012, 177-272.

\section{Демин 1998}

Демин А. С., О художественности древнерусской литературы: Очерки древнерусского мировидения от «Повести временных лет» до сочинений Аввакума, Москва, 1998.

Елеонская 1978

Елеонская А. С., Русская публицистика второй половины семнадиатого века, Москва, 1978. 
Лавров 2018

Лавров А. С., К истории текста «Книги бесед» протопопа Аввакума, Свет Христов просвещает всех: альманах Свято-Филаретовского института, 27, 2018, 11-20.

Лурье 1988

Лурье Я. С., Беседа трех святителей, Словарь книжников и книжности Древней Руси. Bып. 2. Вторая половина XIV-XVI вв. Ч. 1. А-К, Лихачев Д. С., ред., Ленинград 1988, 89-93.

Лыткин, Осипова 2015

Лыткин В. В., Осипова А. В., Источники и методы изучения биографии протопопа Аввакума, Наука. Искусство. Культура, 3 (7), 2015, 77-88.

Матхаузерова 1976

Матхаузерова С., Древнерусские теории искусства слова, Прага, 1976.

Менделеева 2005

Менделеева Д. С., Протопоп Аввакум: литературные облики русского раскола,

Герменевтика древнерусской литературы, 12, Москва, 2005, 186-312.

Мильков 2002

Мильков В. В, Ареопагитики: древнерусская традиция бытования, Древнерусские

Ареопагитики, Макаров А. И., Мильков В. В., Смирнова А. А., подг., Москва, 2002, 9-34. 2008 a

Мильков В. В., Геоцентризм и другие космологические традиции, Космологические произведения в книжности Древней Руси. Часть I. Тексты геоцентрической традиции (= Памятники древнерусской мысли, 4, 1), Мильков В. В., Полянский С. М., подг., С.-Петербург, 2008, 7-40. $2008 \mathrm{~b}$

Мильков В. В., Из «Богословия» Иоанна Дамаскина, Космологические произведения в книжности Древней Руси. Часть I. Тексты геоцентрической традиции (= Памятники древнерусской мысли, 4, 1), Мильков В. В., Полянский С. М., подг. С.-Петербург, 2008, 43-109. 2009 a

Мильков В. В., Космологические тексты плоскостно-комарной традиции, Космологические произведения в книжности Древней Руси. Часть II. Космологические тексты плоскостно-комарной традиции в древнерусской книжности (= Памятники древнерусской мысли, 4, 2), Мильков В. В., Полянский С. М., подг., С.-Петербург, 2009, $7-21$.

$2009 \mathrm{~b}$

Мильков В. В., «Палея Толковая» и содержащаяся в ней проблематика космологического характера, Космологические произведения в книжности Древней Руси. Часть II.

Космологические тексты плоскостно-комарной традиции в древнерусской книжности, (= Памятники древнерусской мысли, 4, 2), Мильков В. В., Полянский С. М., подг., С.-Петербург, 2009, 158-166.

Николаев 2000

Николаев С. И., Что такое «острота телесного ума» протопопа Аввакума, Проблемы истории, русской книжности, культуры и общественного сознания (= Археография и источниковедение Сибири, 20), Ромодановская Е. К., ред., Новосибирск, 2000, 71-76. 2003

Николаев С. И. Курочка протопопа Аввакума и выдра Яна Пасека, Russica Romana, 10, $2003,35-43$.

Панченко 1980

Панченко А. М., Литература переходного века, История русской литературы: В 4-х mm., 1, Ленинград, 1980, 291-407. 
Панченко А. М., Аввакум как новатор, Русская литература, 4, 1982, 142-152. 1996

Панченко А. М., Русская культура в канун петровских реформ, Из истории русской культуры, Т. 3 (ХVII - начало XVIII века), Москва, 1996, 11-264.

Плюханова 1996

Плюханова М. Б., О национальных средствах самоопределения личности: самосакрализация, самосожжение, плавание на корабле, Из истории русской культуры, T. 3 (XVII - начало XVIII века), Москва, 1996, 380-469.

Попов 1869

Попов А. М., Обзор хронографов русской редакции. Вып. II, Москва, 1869.

Робинсон 1967

Робинсон А. И., Исповедь-проповедь (о художественности Жития Аввакума), Историкофилологические исследования. Сборник статей к семидесятипятилетию академика Н. И. Конрада, Москва, 1967, 358-370.

Савельева 2007

Савельева Н. В., Космологическая компиляция «Слово о Святой Троице» и ее бытование в составе древнерусских сборников, Труды Отдела древнерусской литературы, 58,

С.-Петербург, 2007, 557-585.

Сарафанова 1962

Сарафанова Н. С., Произведения древнерусской письменности в сочинениях Аввакума, Труды Отдела древнерусской литературы, 18, Ленинград, 1962, 329-340.

Сарафанова-Демкова 1963

Сарафанова-Демкова Н. С., Иоанн экзарх Болгарский в сочинениях Аввакума, Труды Отдела древнерусской литературы, 19, Москва, Ленинград, 1962, 367-372.

CPЯ XI-XVII 1980

Словарь русского языка XI-XVII вв., 7, Москва, 1980.

CPЯ XI-XVII 2000

Словарь русского языка XI-XVII вв., 25, Москва, 2000.

Творогов 1972

Творогов О.В., К истории жанра Хронографа, Труды Отдела древнерусской литературы, 27, Ленинград, 1972, 203-226.

Турилов, Чернецов 1985

Турилов А. А., Чернецов А. В., Отреченная книга Рафли, Труды Отдела древнерусской литературы, 40, Ленинград, 1985, 260-344.

Хант 1977

Хант П., Самооправдание протопопа Аввакума, Труды Отдела древнерусской литературы, 32, Ленинград, 1977, 70-83.

Burke 2009

Burke P., The Crisis in the Arts of the Seventeenth Century: A Crisis of Representation?, The Journal of Interdisciplinary History, 40, 2, 2009, 239-261.

Chadaeva 2018

Chadaeva O., Two Authors, Two Universes: Cosmological Models in the Works of Simeon

Polotskii and Archpriest Avvakum Petrov, Russian Literature, 99, 2018, 1-37.

Hunt 1975-76

Hunt P., The Autobiography of the Archpriest Avvakum: Structure and Function, Ricerche slavistiche, 2, 1975-76, 159-163.

Lehnhof 2004

Lehnhof K., Paradise Lost and the Concept of Creation, South Central Review, 21, 2004, 15-41. 
Porter1993

Porter W. M., Reading the Classics and Paradise Lost, Lincoln, 1993.

Rajan 1962

Rajan B., Paradise Lost and the Seventeenth Century Reader, Toronto, 1962.

Sarkar 2012

Sarkar M., Cosmos and Character in Paradise Lost, New York, 2012.

Shoulson 2001

Shoulson J. S., Milton and the Rabbis: Hebraism, Hellenism, and Christianity, New York, 2001

Verbart 1995

Verbart A., Fellowship in Paradise lost: Vergil, Milton, Wordsworth, Amsterdam. 1995.

Werman 1995

Werman G., Milton and Midrash, Washington, DC, 1995.

\section{References}

Bulanin D. M., The Lost Manuscript Source of Russian Chronograph: (Attempt to Its Reconstruction), Rossica Antiqua, 13, 1-2, 2016, 99-136.

Burke P., The Crisis in the Arts of the Seventeenth Century: A Crisis of Representation?, The Journal of Interdisciplinary History, 40, 2, 2009, 239-261.

Chadaeva O., Two Authors, Two Universes: Cosmological Models in the Works of Simeon Polotskii and Archpriest Avvakum Petrov, Russian Literature, 99, 2018, 1-37.

Demin A. S., O khudozhestvennosti drevnerusskoi literatury: Ocherki drevnerusskogo mirovideniia ot "Povesti vremennykh let” do sochinenii Avvakuma, Moscow, 1998.

Eleonskaya A. S., Russkaia publitsistika vtoroi poloviny semnadtsatogo veka, Moscow, 1978.

Gerasimova N. M., Poetika "Zhitiia” Avvakuma, Eadem, Pragmatika teksta: fol'klor, literatura, kul'tura, St. Petersburg, 2012, 177-272.

Hunt P., The Autobiography of the Archpriest Avvakum: Structure and Function, Ricerche slavistiche, 2, 1975-76, 159-163.

Hunt P. Samoopravdanie protopopa Avvakuma, Trudy Otdela drevnerusskoi literatury, 32, Leningrad, 1977, 70-83.

Lavrov A. S., On the Textual History of the Book of Conversations by Archpriest Avvakum, The Quarterly Journal of St. Philaret's Christian Orthodox Institute, 27, 2018, 11-20.

Lehnhof K., Paradise Lost and the Concept of Creation, South Central Review, 21, 2004, 15-41.

Lurie Ya. S., Beseda trekh sviatitelei, Slovar' knizhnikov i knizhnosti Drevnei Rusi. Vyp. 2. Vtoraia polovina XIV-XVI vv. Ch. 1. A-K, Likhachev D. S., ed., Leningrad, 1988, 89-93.

Lytkin V. V., Osipova A. V., Sources and methods of studying the biography of Archpriest Avvakum, Science. Arts. Culture, 3 (7), 2015, 77-88.

Mathauzerová S., Drevnerusskie teorii iskusstva slova, Praga, 1976.
Mendeleeva D. S., Protopop Avvakum: literaturnye obliki russkogo raskola, Germenevtika drevnerusskoi literatury, 12, Moscow, 2005, 186-312.

Milkov V. V, Areopagitiki: drevnerusskaia traditsiia bytovaniia, Drevnerusskie Areopagitiki, Makarov A. I., Milkov V. V., Smirnova A. A., eds., Moscow, 2002, 9-34.

Milkov V. V., Geotsentrizm i drugie kosmologicheskie traditsii, Kosmologicheskie proizvedeniia $v$ knizhnosti Drevnei Rusi. Chast' I. Teksty geotsentricheskoi traditsii, Milkov V. V., Polyansky S. M., eds., St. Petersburg, 2008, 7-40.

Milkov V. V., Iz “Bogosloviia” Ioanna Damaskina, Kosmologicheskie proizvedeniia v knizhnosti Drevnei Rusi. Chast' I. Teksty geotsentricheskoi traditsii, Milkov V. V., Polyansky S. M., eds., St. Petersburg, 2008, 43-109.

Milkov V. V., Kosmologicheskie teksty ploskostno-komarnoi traditsii, Kosmologicheskie proizvedeniia v knizhnosti Drevnei Rusi. Chast' II. Kosmologicheskie teksty ploskostno-komarnoi traditsii v drevnerusskoi knizhnosti, Milkov V. V., Polyansky S. M., eds., St. Petersburg, 2009, 7-21.

Milkov V. V., "Paleia Tolkovaia" i soderzhashchaiasia $\mathrm{v}$ nei problematika kosmologicheskogo kharaktera, Kosmologicheskie proizvedeniia v knizhnosti Drevnei Rusi. Chast' II. Kosmologicheskie teksty ploskostno-komarnoi traditsii $v$ drevnerusskoi knizhnosti, Milkov V. V., Polyansky S. M., eds., St. Petersburg, 2009, 158-166.

Nikolaev S. I., Chto takoe "ostrota telesnogo uma" protopopa Avvakuma, Problemy istorii, russkoi knizhnosti, kul'tury $i$ obshchestvennogo soznaniia, Romodanovskaya E. K., ed., Novosibirsk, 2000, 71-76.

Nikolaev S. I. Kurochka protopopa Avvakuma i vydra Iana Paseka, Russica Romana, 10, 2003, 35-43.

Panchenko A. M., Literatura perekhodnogo veka, Istoriia russkoi literatury: V 4-kh tt., 1, Leningrad, 1980, 291-407. 
Panchenko A. M., Avvakum kak novator, Russkaya literatura, 4, 1982, 142-152.

Panchenko A. M., Russkaia kul'tura v kanun petrovskikh reform, Iz istorii russkoi kul'tury, T. 3 (XVII nachalo XVIII veka), Moscow, 1996, 11-264.

Pliukhanova M. B., O natsional'nykh sredstvakh samoopredeleniia lichnosti: samosakralizatsiia, samosozhzhenie, plavanie na korable, Iz istorii russkoi kul'tury, T. 3 (XVII - nachalo XVIII veka), Moscow, 1996, 380-469.

Porter W. M., Reading the Classics and Paradise Lost, Lincoln, 1993.

Rajan B., Paradise Lost and the Seventeenth Century Reader, Toronto, 1962.

Robinson A. I. Ispoved'-propoved' (o khudozhestvennosti Zhitiia Avvakuma), Istoriko-filologicheskie issledovaniia. Sbornik statei $k$ semidesiatipiatiletiiu akademika N. I. Konrada, Moscow, 1967, 358-370.

Sarafanova N. S. Proizvedeniia drevnerusskoi pis'mennosti v sochineniiakh Avvakuma, Trudy Otdela drevnerusskoi literatury, 18, Leningrad, 1962, 329-340.

Sarafanova-Demkova N. S. Ioann ekzarkh Bolgarskii v sochineniiakh Avvakuma, Trudy Otdela drevnerusskoi literatury, 19, Moscow, Leningrad, 1962, 367-372.

Sarkar M., Cosmos and Character in Paradise Lost, New York, 2012.

Savelieva N. V. Kosmologicheskaia kompiliatsiia "Slovo o Sviatoi Troitse" i ee bytovanie v sostave drevnerusskikh sbornikov, Trudy Otdela drevnerusskoi literatury, 58, St. Petersburg, 2007, 557-585.

Shoulson J. S., Milton and the Rabbis: Hebraism, Hellenism, and Christianity, New York, 2001

Tvorogov O.V. K istorii zhanra Khronografa, Trudy Otdela drevnerusskoi literatury, 27, Leningrad, 1972, 203-226.

Turilov A. A., Chernetsov A. V. Otrechennaia kniga Rafli, Trudy Otdela drevnerusskoi literatury, 40, Leningrad, 1985, 260-344.

Verbart A., Fellowship in Paradise lost: Vergil, Milton, Wordsworth, Amsterdam, 1995.

Vinogradov V. V., O zadachakh stilistiki. Nabliudeniia nad stilem Zhitiia protopopa Avvakuma, Idem, O iazyke khudozhestvennoi prozy, Moscow, 1980, 3-41.

Werman G., Milton and Midrash, Washington, DC, 1995.

\section{Olga Chadaeva, Ph.D.}

Univerzita Palackého v Olomouci, Filozofická fakulta,

Katedra slavistiky, Sekce rusistiky, odborný asistent

Křížkovského 10, 77180 Olomouc

Česká republika / Czech Repulbic

e-mail olga.chadaeva@upol.cz 